\title{
High mortality risk of prostate cancer patients in Asia and West Africa: A systematic review
}

Jude O. Okoye

Department of Medical Laboratory Science, Faculty of Health Sciences and Technology, College of Medicine, Nnamdi Azikiwe University, Nnewi Campus, Anambra State, Nigeria

\begin{tabular}{|c|}
\hline Access this article online \\
\hline Website: www.avicennajmed.com \\
\hline DOI: 10.4103/ajm.ajm_19_20 \\
\hline Quick Response Code: \\
\hline \\
\hline
\end{tabular}

\begin{abstract}
Globally, prostate cancer (PCa) is the second most preponderant cancer in men. It contributes to the high mortality-to-incidence ratio reported in West Africa and Asia largely due to low screening. The mortality risk is determined or predicted based on the prevalence of high-risk or aggressive PCa using a scoring or grading system such as Gleason score (GS), Gleason grade (GG), and prostate-specific antigen (PSA) level. In this review, peer-reviewed articles found on databases such as Google Scholar, Scopus, Web of Science, PubMed Central and, EMBASE were selected based on adherence to clinical guidelines for the classification of PCa. In West Africa and Asia, the result revealed that the frequency of high-risk PCa was $42 \%$ and $51.2 \%$ based on GS, $48.8 \%$ and $25.3 \%$ based on GG pattern, and $87.5 \%$ and $44.3 \%$ based on PSA level $>10 \mathrm{ng} / \mathrm{mL}$, respectively. Data revealed a high prevalence of high-risk PCa both in West Africa and Asia when compared with developed countries. However, the prevalence of high-risk PCa is higher in West Africa than in Asia. Studies have shown that high-risk PCas are associated with germline mutations and such mutations are prevalent in blacks and Asians than in whites. Thus, testing for germline mutations in patients with $G S$ of $\geq 7, G G \geq 3$, high prostate density, low prostate volume, and PSA levels of $>4.0 \mathrm{ng} / \mathrm{mL}$ may identify those at risk of developing lethal PCa and could reduce the mortality rates in Asia and West Africa.
\end{abstract}

Key words: Gleason grade, Gleason system, mortality risk, prostate cancer, PSA level

\section{INTRODUCTION}

Benign prostate hyperplasia (BPH) accounts for $78.3 \%$ of all prostate-related diagnoses and increases from $20 \%$ to $90 \%$ in men who are $40-80$ years of age, whereas prostatic adenocarcinoma accounts for $92.4 \%-96.7 \%$ of all malignant tumors in the prostate. ${ }^{[1-3]}$ Globally, the odds of developing prostate cancer (PCa) are 1 in 18 and the odds range from 1 in 52 for low sociodemographic index (SDI) countries to 1 in 9 in high SDI countries. ${ }^{[4]}$ However, the mortality rate per new cases appears to be higher in the former than the latter. The reason for this could be linked to poverty, family history, genetics, and race. ${ }^{[5]}$ This review evaluated and compared the aggressiveness of PCa in West Africa and Asia against that of developed countries, using diagnostic

Address for correspondence: Mr. Jude Ogechukwu Okoye, Ph.D inview, Department of Medical Laboratory Science, Faculty of Health Sciences and Technology, College of Medicine, Nnamdi Azikiwe University, Nnewi Campus, Anambra State, Nigeria. E-mail: jog.okoye@unizik.edu.ng tools such as Gleason score (GS), Gleason grade (GG), and prostate-specific antigen (PSA) level.

\section{MATERIALS AND METHODS}

Peer-reviewed articles published between the year 2000 and 2020 were selected and screened using the PRISMA standard [Figure 1]. Sources of articles include Google Scholar, Scopus, Web of Science, PubMed Central, and EMBASE. Full-texts on clinical risk stratification of $\mathrm{PCa}$ cases were selected based on authors' adherence to the recommendations and reports

This is an open access journal, and articles are distributed under the terms of the Creative Commons Attribution-NonCommercial-ShareAlike 4.0 License, which allows others to remix, tweak, and build upon the work non-commercially, as long as appropriate credit is given and the new creations are licensed under the identical terms.

For reprints contact: reprints@medknow.com

Cite this article as: Okoye JO. High mortality risk of prostate cancer patients in Asia and West Africa: A systematic review. Avicenna J Med 2020;10:93-101. 
of the National Comprehensive Cancer Network (NCCN), and International Society of Urological Pathology. ${ }^{[6,7]}$ To determine mortality risk or prevalence of aggressive PCa among Asian and West African patients in literature, $\mathrm{PCa}$ was clinically classified into low-, intermediate-, and highrisk groups using grading or scoring systems such as Gleason score (GS: $\leq 6,7$, and $\geq 8$ ), Gleason grade (GG: 1 through $5)$ and PSA level $(<4,4-10$, and $>10 \mathrm{ng} / \mathrm{mL})$. All cases with unknown or unassigned GS, GG, or PSA level were excluded. Chi-square analysis (GraphPad Prism version 6) was used to compare the frequency of high-risk PCa between West Africa and Asia.

\section{MORTALITY-TO-INCIDENCE RATIOS AND SCREENING FOR PROSTATE CANCER}

Over 1 million men are diagnosed with PCa every year with approximately $28 \%$ mortality ${ }^{[8]}$ Data from the GLOBOCAN 2012 report, as reviewed by Chen et al. ${ }^{[9]}$ show a significant inverse relationship between mortality-to-incidence ratios (MIRs) and life expectancy $(P=0.0002)$, with Nigeria having the second-lowest life expectancy ( 55 years) and the highest MIR (80.6) in the world. According to the report, the MIR (pooled) is also higher in Asian countries (51.6) than in the USA (13.0), Germany (18.4), and UK (23.3). The lower pooled MIR (18.2) and high life expectancy (80.3 years) in developed countries (the USA, Germany, and UK) when compared with that of Africa and Asia may be linked to low poverty status, high health budget, awareness and high screening services in developed countries. This is further underscored by the fact that a higher incidence rate of PCa is seen in the UK's affluent regions, whereas a higher mortality rate is observed in the UK's deprived regions. ${ }^{[10]}$ Lower incidence of $\mathrm{PCa}$ is reported in China (9.1) than in the USA (75.7); however, higher mortality rate per new cases is reported in China than in the USA. ${ }^{[11-15]}$ The latter could be ascribed to higher prevalence aggressive PCa in China (30\%) than in the USA $(0.5 \%){ }^{[13-15]}$ Despite China's advanced economy, it accounts for $34 \%$ of the total PCa-related mortality in Asia. ${ }^{[16]}$ This suggests that there are other co-founding factors to high mortality rate in Asia apart from poverty. To detect PCa early, some biomarkers have being proposed. One such biomarker is the PSA.

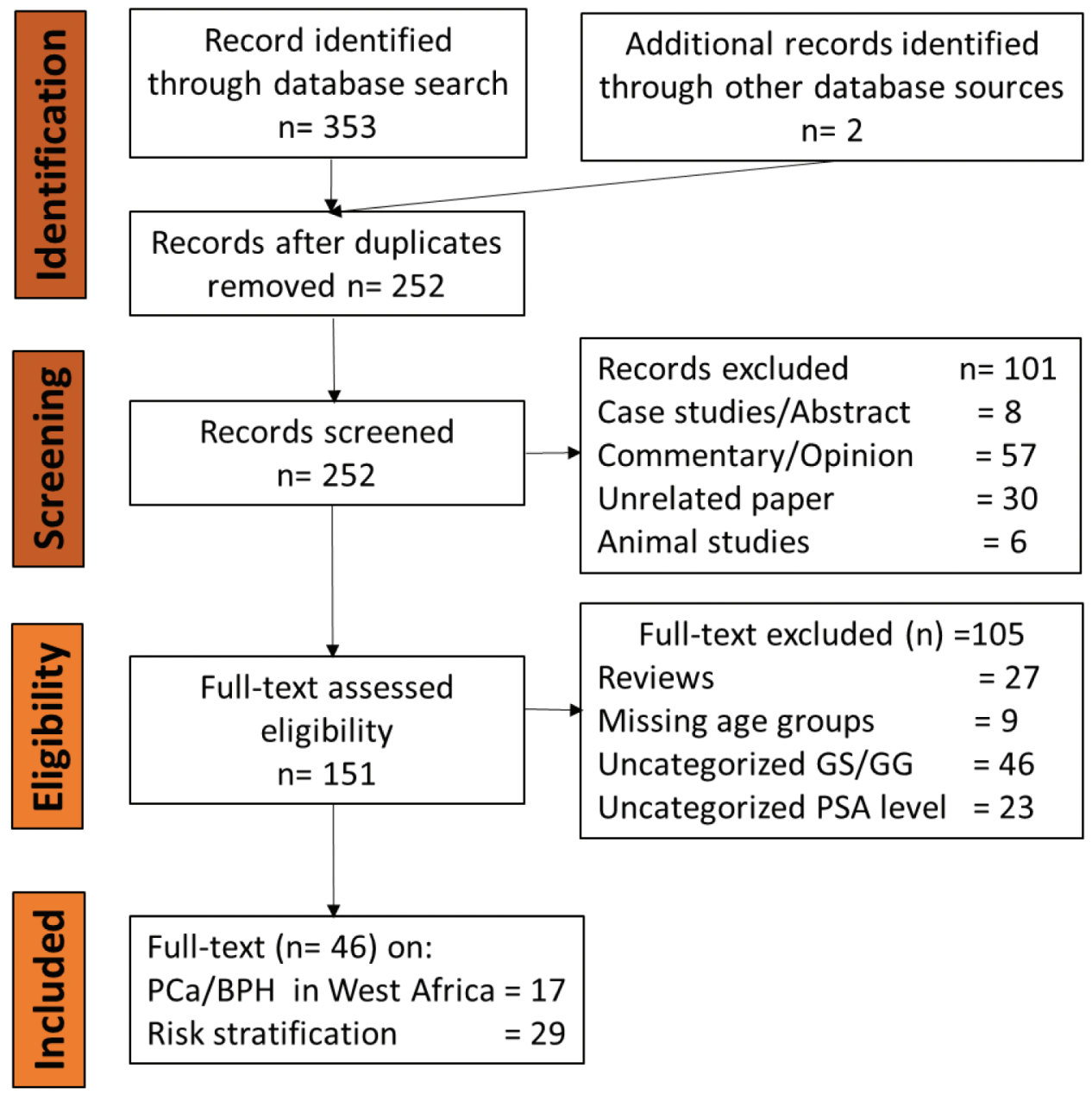

Figure 1: PRISMA flow diagram on prevalence of $\mathrm{PCa} / \mathrm{BPH}$ and its risk stratification 
Considering the sensitivity $(81.9 \%-89.5 \%)$ and specificity $(38.2 \%-52.3 \%)$ of PSA (at $>4 \mathrm{ng} / \mathrm{mL}$ ), many countries including Asian countries have been scaling up PCa screening. ${ }^{[17]}$ However, the starting age for the screening remains controversial considering the high cost of a nationwide screening. It is hypothesized that the high mortality rate associated with PCa is linked to the age group commonly selected for screening ( $>70$ years). As a good number of affected individuals stand the chance of being missed due to exclusion, the age group of 5059 years is currently being advocated for screening. ${ }^{[18,19]}$ Although the PSA level of $>4 \mathrm{ng} / \mathrm{mL}$ is considered appropriate for PCa screening, a PSA level of $\geq 3 \mathrm{ng}$ / $\mathrm{mL}$ has also been recommended for screening among men $\leq 60$ years. $^{[20,21]}$ It is believed that this will reduce the number of participants that are missed due to agerelated low levels of PSA. Despite the fact that PCa is the leading cause of mortality in African men, ${ }^{[22]}$ there is little or no concerted effort for a nationwide screening for PCa in West Africa. Most of the screening exercises are academic-related. This has minimal impact on MIR because there is hardly any follow-up on individuals with abnormal PSA, hence the high prevalence of occult PCa in Nigeria (8\%). ${ }^{[23]}$ Due to the free travel agreement between the Nigeria government and the governments of other West African countries, Nigeria is also inhabited by men from other west African countries. Thus Nigeria, the most populous country in Africa, is largely a microcosm of the West African subregion. The prevalence of abnormal PSA among apparently healthy men in West Africa ranges from $6.6 \%$ to $11.2 \%,{ }^{[24-27]}$ whereas the combined prevalence of abnormal digital rectal examination (DRE) and PSA $>4 \mathrm{ng} / \mathrm{mL}$ ranges from $5.8 \%$ to $7.1 \%,{ }^{[25,26]}$
In West Africa, the frequency distribution of $\mathrm{BPH}$ and $\mathrm{PCa}$ across all age groups appears to be similar due to the fact that the peak incidence of both diseases occurs in the age group of 60-69 years [Figure 2 and Table 1]. ${ }^{[23,28-43]}$ Although the symptoms of $\mathrm{PCa}$ and $\mathrm{BPH}$ are also similar, the latter is yet to be established as a direct precursor for the former. However, according to a prospective study carried out by Aghaji and Odoemene, ${ }^{[44]} 92 \%$ of patients (age range $=64-89$ years) who were diagnosed with BPH developed PCa one to 10 years postprostatectomy (mean time interval $=6.6$ years). According to their follow-up report, approximately $21 \%$ of the patients under surveillance died after a period of 1 year. Based on these reports, it is recommended that patients diagnosed of $\mathrm{BPH}$ who have had prostatectomy should be actively monitored and tested for germline mutations associated with aggressive $\mathrm{PCa}$, especially those who are $>54$ years.

\section{GLEASON SCORE OF PROSTATE CANCER IN WEST AFRICA AND ASIA}

GS is a prognostic tool that informs the course of treatment for patients diagnosed with PCa. It identifies cases that are likely to be metastatic. ${ }^{[7]}$ Using GS to stratify the death risk among men with $\mathrm{PCa}$, the frequency of low-risk (GS $\leq 6)$, intermediate-risk (GS7), and high-risk (GS $\geq 8$ ) PCa ranges from $42 \%$ to $53 \%, 36 \%$ to $41 \%$, and $6 \%$ to $15 \%$, respectively, in the USA. ${ }^{[45-47]}$ In the UK, the frequency of $\mathrm{GS} \leq 6$, GS 7 , and GS $\geq 8$ ranges from $38 \%$ to $56 \%, 34 \%$ to $38 \%$, and $10 \%$ to $21 \%$, respectively, ${ }^{[48-50]}$ whereas in Germany the frequency is $11 \%, 48 \%$, and $36 \%$, respectively. ${ }^{[1]}$ These figures suggest that the prevalence of high-risk PCa is lower in the USA, the UK, and Germany than in West Africa and



Figure 2: Frequency distribution of benign prostate hyperplasia across age groups, ${ }^{[28-33]}$ showing higher and lower frequency of BPH in the age groups of $60-69$ and 30-39 years, respectively, when compared with other groups. It also shows that BPH can be found in individuals younger $<40$ years of age 
Asia [Table 2]..$^{[3,28,29,31,36,37,40,41,52-61]}$ An earlier study shows that the death risk of patients with a GS of 7 to 10 range from $29 \%$ to $43 \%$, irrespective of age. ${ }^{[62]}$ This might be due to a lower prevalence of pathogenic mutation (BRCA1/2) in GS $\leq 6(0.6 \%)$ than in GS $\geq 7(1.2 \%-3.4 \%)$. ${ }^{[63]}$ Another study shows that the metastasis hazard ratio of GS8 and
GS9 is 3.5 and 9.3, respectively, when compared with GS7. ${ }^{[64]}$

Currently, the Gleason grading pattern (GG) is being proposed by John Hopkins Hospital as a more reliable tool than the Gleason scoring pattern. ${ }^{[65]}$ Of note, the GG pattern

\begin{tabular}{|c|c|c|c|c|c|c|c|c|c|}
\hline \multirow[t]{2}{*}{ Year } & \multirow[t]{2}{*}{ City } & \multirow[t]{2}{*}{ No. of cases } & \multicolumn{7}{|c|}{ Age range (\%) } \\
\hline & & & $30-39$ & $40-49$ & 50-59 & $60-69$ & $70-79$ & $80-89$ & $\geq 90$ \\
\hline${ }^{[34]} 2019$ & Port H. & 676 & $4(0.6)$ & $21(3.1)$ & $122(18.1)$ & $224(33.1)$ & $223(33.0)$ & $73(10.8)$ & $9(1.3)$ \\
\hline${ }^{[35]} 2018$ & Calabar & 563 & I $(0.2)$ & II (2.0) & $104(18.5)$ & $213(37.8)$ & $153(27.2)$ & $59(10.5)$ & $22(3.9)$ \\
\hline${ }^{[36]} 2018$ & Calabar & 111 & $0(0.0)$ & $4(3.6)$ & $20(18.0)$ & $39(35.1)$ & $39(35.1)$ & $6(5.4)$ & $3(2.7)$ \\
\hline${ }^{[37]} 2018$ & Zaria & 211 & $2(0.8)$ & $7(3.3)$ & 38 (I8.3) & 77 (36.5) & $61(29.0)$ & $23(10.5)$ & $3(1.5)$ \\
\hline${ }^{[23]} 2017 *$ & Lagos & 7 & $0(0.0)$ & $0(0.0)$ & $3(42.9)$ & I (I4.3) & $2(28.6)$ & I (I4.3) & $0(0.0)$ \\
\hline${ }^{[30]} 2017$ & Enugu & 160 & $7(4.4)$ & $35(21.9)$ & $70(43.8)$ & $34(21.3)$ & $13(8.1)$ & I $(0.6)$ & $0(0.0)$ \\
\hline${ }^{[38]} 2015$ & Ibadan & 50 & $0(0.0)$ & I $(2.0)$ & $4(8.0)$ & $20(40.0)$ & $25(50.0)$ & $0(0.0)$ & $0(0.0)$ \\
\hline${ }^{[39]} 2015$ & Zaria & 145 & $2(1.3)$ & $7(4.6)$ & $28(18.5)$ & $59(39.0)$ & 49 (32.2) & $0(0.0)$ & $0(0.0)$ \\
\hline${ }^{[29]} 2015$ & Lagos & 89 & $0(0.0)$ & $2(2.2)$ & $8(9.0)$ & 35 (39.3) & 35 (39.3) & $9(10.1)$ & $0(0.0)$ \\
\hline${ }^{[40]} 2013$ & Lagos & 35 & $0(0.0)$ & I (2.9) & $10(28.6)$ & $24(68.6)$ & $0(0.0)$ & $0(0.0)$ & $0(0.0)$ \\
\hline${ }^{[4} 2012$ & Port H. & 383 & $0(0.0)$ & $4(1.0)$ & $56(14.6)$ & 110 (28.7) & $154(40.2)$ & $55(14.4)$ & $4(1.0)$ \\
\hline$[31] 2011$ & Benin & 252 & $0(0.0)$ & I (4.0) & $36(14.3)$ & 88 (34.9) & 95 (37.7) & 28 (II.I) & $4(1.6)$ \\
\hline${ }^{[28]} 20 \mathrm{II}$ & Lagos & 222 & $0(0.0)$ & $9(4.1)$ & $32(14.4)$ & $95(42.8)$ & $74(33.3)$ & $9(4.1)$ & $3(1.4)$ \\
\hline${ }^{[42]} 2010$ & Ilorin & 90 & $0(0.0)$ & $4(4.4)$ & $22(24.4)$ & 31 (34.4) & $24(26.7)$ & $8(8.9)$ & I (I.I) \\
\hline${ }^{[43]} 2005$ & Ilorin & 114 & I (0.9) & $4(3.5)$ & $16(14.0)$ & 43 (37.7) & $30(26.3)$ & $7(6.1)$ & $4(3.5)$ \\
\hline${ }^{[33]} 2004$ & Kano & 37 & $0(0.0)$ & $2(5.4)$ & $8(21.6)$ & $18(48.6)$ & $6(16.2)$ & $2(5.4)$ & I (2.7) \\
\hline${ }^{[32]} 2000$ & Zaria & 95 & $0(0.0)$ & $4(4.2)$ & $19(20.0)$ & $4 \mid(43.2)$ & $29(30.5)$ & $2(2.1)$ & $0(0.0)$ \\
\hline Total & & 3240 & $17(0.5)$ & 117 (3.6) & $596(18.4)$ & II52(35.6) & $1012(31.2)$ & $283(8.7)$ & 54 (I.7) \\
\hline
\end{tabular}

$\mathrm{H}=$ harcourt

*Autopsy based (occult PCa)

The table shows higher and lower frequency of PCa in the age groups of 60-69 and 30-39 years, respectively, when compared with other groups. It also shows that PCa can found in individuals younger $<40$ years of age

\begin{tabular}{|c|c|c|c|c|}
\hline \multirow[t]{3}{*}{ Authors/reference } & \multirow[t]{3}{*}{ City/country/region } & \multicolumn{3}{|c|}{ Classification of risk } \\
\hline & & Low & Inter-mediate & High \\
\hline & & $\mathbf{G S} \leq 6$ & GS 7 & $\mathbf{G S} \geq 8$ \\
\hline Obiorah and Ofuru ${ }^{[34]}$ & Port H. & $282(4 I .7)$ & $97(14.7)$ & $297(43.9)$ \\
\hline Abubakar et al. ${ }^{[37]}$ & Zaria & $68(32.2)$ & $43(20.4)$ & $100(47.4)$ \\
\hline Isiwele et al. ${ }^{[35]}$ & Calabar & $5(0.9)$ & $297(52.8)$ & $26 I(46.4)$ \\
\hline Bassey et al. ${ }^{[36]}$ & Calabar & $42(44.2)$ & $20(2 I . I)$ & $33(33.4)$ \\
\hline Nwafor et al. ${ }^{[29]}$ & Lagos & $21(33.9)$ & $20(32.3)$ & $21(33.9)$ \\
\hline Ikuerowo et al. ${ }^{[40]}$ & Lagos & II (25.6) & $20(46.5)$ & 12 (27.9) \\
\hline Sapira et al. ${ }^{[4 I]}$ & Port H. & $58(30.9)$ & $53(28.2)$ & $77(41.0)$ \\
\hline Ugare et al. ${ }^{[52]}$ & Calabar & $33(37.1)$ & $22(24.7)$ & $34(38.2)$ \\
\hline Anunobi et al. ${ }^{[28]}$ & Lagos & $112(50.9)$ & $20(9.1)$ & $88(40.0)$ \\
\hline Forae et al. ${ }^{[3 !]}$ & Benin & $122(58.1)$ & $20(16.4)$ & $68(32.4)$ \\
\hline Total $(N=2357)$ & West Africa & $754(32.0)$ & $612(26.0)$ & 991 (42.0) \\
\hline Uemura et al. ${ }^{[53]}$ & UFO & $176(9.1)$ & $465(24.1)$ & $1288(66.8)$ \\
\hline Faroog et al. ${ }^{[3]}$ & India & II (19.3) & $21(36.8)$ & $25(43.9)$ \\
\hline Awang et al..$^{[54]}$ & Malaysia & $10(12.8)$ & $57(73.1)$ & II (I4.I) \\
\hline Heo et al. ${ }^{[55]}$ & Korea & $218(32.3)$ & $180(26.7)$ & $277(41.0)$ \\
\hline Xu et al..$^{[56]}$ & China & $10(9.4)$ & $22(20.8)$ & $69(65.1)$ \\
\hline Zhu et al. ${ }^{[57]}$ & China & $47(26.7)$ & $74(42.0)$ & $55(31.3)$ \\
\hline Sarikaya et al. ${ }^{[58]}$ & Turkey & $66(44.6)$ & $35(23.6)$ & $47(3 \mid .8)$ \\
\hline Osman et al. ${ }^{[59]}$ & Saudi Arabia & $19(25.0)$ & $24(31.6)$ & $33(43.4)$ \\
\hline Shahab et al. ${ }^{[60]}$ & Indonesia & $21(47.7)$ & $16(36.4)$ & 7 (15.9) \\
\hline Tsang et al. ${ }^{[61]}$ & Hong Kong & $229(79.8)$ & $42(14.6)$ & $16(5.6)$ \\
\hline Total $(N=3571)$ & Asia & $807(22.6)$ & $936(26.2)$ & $\begin{array}{c}1828 \\
(51.2)\end{array}$ \\
\hline
\end{tabular}

$\mathrm{H}=$ harcourt, WA = West Africa, fight against prostate cancer = UFO (countries: $n=8$;

Japan, China, South Korea, Singapore, Malaysia, Thailand, Taiwan, India)

The table shows higher prevalence of intermediate-risk and high-risk $P C a$ in Asia than in West Africa $(P=0.211$ and $P<0.001$, respectively $)$ and shows higher prevalence of lowrisk PCa in West Africa than in Asia $(P<0.001)$ 
is yet to be fully and globally used in clinical diagnosis, especially in Africa. In the USA, the prevalence of GG1, GG2, GG3, GG4, and GG5 is approximately $40 \%, 34 \%, 13 \%$, 9\%, and 4\%, respectively. ${ }^{[46]}$ Again, these figures show that the prevalence of high-risk PCa is higher in West Africa and Asia [Table 3] than in the USA. ${ }^{[35-37,39,52,54,58,66-71]}$ Unlike the GS system which revealed significantly and significantly higher prevalence of intermediate-risk and high-risk PCa in Asia than in West Africa $(P=0.211$ and $P<0.001$, respectively), the more reliable GG system revealed significantly higher prevalence of both intermediate-risk (GG3) and high-risk (GG4/5) PCa in West Africa than in Asia $(P<0.001)$. The tool shows that patients with GG1, GG2, GG3, GG4, and GG5 have risk-free survival of $96 \%, 88 \%, 63 \%, 48 \%$, and $26 \%$, respectively. ${ }^{[72]}$ The gradual decline in risk-free survival from GG1 to GG5 may be related to the increase in frequency of ataxiatelangiectasia mutated (ATM)/BRCA1/2 mutations from GG1 through GG5; $1.5 \%, 3.0 \%, 8.3 \%$, $5.6 \%$, and $6.5 \%$, respectively. ${ }^{[73]}$ Wei et al ${ }^{[68]}$ also observed a higher frequency of GG5 in carriers of germline mutations (BRCA1/2 and ATM) than in noncarriers (65\% vs. $46 \%$ ). They also observed high metastasis in carriers than in noncarriers ( $71 \%$ vs. $58 \%)$. As most of the PCa cases in West Africa and Asia are within GG3 to GG5 [Table 3], it is hypothesized that the risk-free survival of patients with PCa is low, especially in West Africa. This is supported by studies that show that $50 \%-75 \%$ of PCa observed in West Africa are either advanced, poorly differentiated or metastatic. ${ }^{[20-23]}$

Furthermore, based on the PSA level, the prevalence of low-, intermediate-, and high-risk PCa in the USA is $23 \%$, $68 \%$, and $10 \%$, respectively. ${ }^{[74]}$ This report also shows that the prevalence of high-risk PCa is higher in West Africa and Asia [Table 4] than in the USA. ${ }^{[33,35-37,58,60,74-76]}$ In addition, the prevalence of high-risk PCa, based on PSA $>10 \mathrm{ng} /$ $\mathrm{mL}$, is higher in West Africa than in Asia $(P<0.001)$. This latter could be considered a tiebreaker between GS and GG patterns of risk stratification and supports the fact that

Table 3: Risk stratification of prostate cancer patients by Gleason grade

\begin{tabular}{|c|c|c|c|c|c|c|}
\hline \multirow[t]{3}{*}{ Authors/reference } & \multirow{3}{*}{$\begin{array}{l}\text { City/country/ } \\
\text { region }\end{array}$} & \multicolumn{5}{|c|}{ Risk stratification } \\
\hline & & \multicolumn{2}{|c|}{ Low } & \multirow{2}{*}{$\begin{array}{c}\text { Inter-mediate } \\
\text { GG3 }\end{array}$} & \multicolumn{2}{|c|}{ High } \\
\hline & & GGI & GG2 & & GG4 & GG5 \\
\hline Emiogun et al. ${ }^{[66]}$ & Lagos & $37(12.9)$ & $36(12.5)$ & 33 (II.5) & $58(20.2)$ & $123(42.9)$ \\
\hline Isiwele et al..$^{[35]}$ & Calabar & $5(0.9)$ & $48(8.5)$ & $249(44.2)$ & $202(35.9)$ & $59(10.5)$ \\
\hline Bassey et al. ${ }^{[36]}$ & Calabar & $12(11.2)$ & $4(3.7)$ & $38(35.5)$ & $34(31.8)$ & $19(17.8)$ \\
\hline Abubakar et al..$^{[3]]}$ & Zaria & 68 (32.2) & $13(6.2)$ & $29(13.7)$ & $63(29.9)$ & $38(18.0)$ \\
\hline Oluwole et al. ${ }^{[39]}$ & Zaria & $45(31.0)$ & $10(6.9)$ & $60(4 \mid .4)$ & $30(20.7)$ & $0(0.0)$ \\
\hline Ugare et al. ${ }^{[52]}$ & Calabar & $I(I . I)$ & $8(9.0)$ & $22(24.7)$ & 48 (53.9) & $10(11.2)$ \\
\hline Total $(N=1403)$ & West Africa & $168(12.0)$ & $119(8.5)$ & $431(30.7)$ & $435(31.0)$ & $250(17.8)$ \\
\hline Taguchi et al. ${ }^{[67]}$ & Japan & $119(11.6)$ & 395 (38.6) & $148(14.5)$ & $225(22.0)$ & 135 (I 3.2$)$ \\
\hline Wei et al[.68] & China & $13(4.2)$ & $25(8.0)$ & 38 (I2.2) & $86(27.5)$ & $150(48.1)$ \\
\hline Awang et al..[54] & Malaysia & $10(12.8)$ & $36(46.2)$ & $21(26.9)$ & $\mathrm{I}(\mathrm{I} .3)$ & $10(12.8)$ \\
\hline Cho et al.[69] & South Korea & 1349 (46.8) & $571(19.8)$ & $410(14.2)$ & $406(14.1)$ & $147(5.1)$ \\
\hline Yeong et al. ${ }^{70]}$ & Singapore & $249(39.0)$ & $258(40.4)$ & $79(12.4)$ & $31(4.9)$ & $21(3.3)$ \\
\hline Khan et al..71] & Pakistan & $0(0.0)$ & $7(12.3)$ & $8(14.0)$ & $18(31.6)$ & $24(42.1)$ \\
\hline Sarikaya et al. ${ }^{[58]}$ & Turkey & $66(44.6)$ & $21(14.2)$ & $14(9.5)$ & $17(11.5)$ & $30(20.3)$ \\
\hline Total $(N=5|4|)$ & Asia & 1809 (35.2) & $1313(25.5)$ & $718(14.0)$ & $784(15.2)$ & $517(10.1)$ \\
\hline
\end{tabular}

The table shows higher prevalence of GG4 in both in West Africa and Asia than other GGs. It also reveals higher prevalence of intermediate-risk (GG3) and high-risk (GG4/5) $\mathrm{PCa}$ in West Africa than in Asia $(P<0.00 \mathrm{I})$ but shows lower prevalence of low-risk $(\mathrm{GGI} / 2) \mathrm{PCa}$ in West Africa than in Asia $(P<0.00 \mathrm{I})$

\begin{tabular}{|c|c|c|c|c|}
\hline \multirow[t]{3}{*}{ Authors/reference } & \multirow[t]{3}{*}{ City/country/region } & \multicolumn{3}{|c|}{ Classification of risk (PSA level) } \\
\hline & & Low & Inter-mediate & High \\
\hline & & $<4 \mathrm{ng} / \mathrm{mL}$ & 4-10 ng/mL & $>10 \mathrm{ng} / \mathrm{mL}$ \\
\hline Abubakar et al. ${ }^{[37]}$ & Zaria & $0(0.0)$ & $16(7.6)$ & $195(92.4)$ \\
\hline Bassey et al. ${ }^{[36]}$ & Calabar & $7(6.9)$ & $14(13.9)$ & $80(79.2)$ \\
\hline Ikuerowo et al. ${ }^{[35]}$ & Lagos & $0(0.0)$ & $2(4.7)$ & $41(95.3)$ \\
\hline Emokpae et al. ${ }^{[33]}$ & Kano & $3(8.1)$ & $7(20.6)$ & $27(73.0)$ \\
\hline Total $(N=392)$ & West Africa & $10(2.5)$ & $39(11.9)$ & $343(87.5)$ \\
\hline Wang et al. ${ }^{[75]}$ & China & $7(1.6)$ & $173(40.2)$ & $250(58.1)$ \\
\hline Huang et al. ${ }^{[76]}$ & China & $9(6.6)$ & $37(27.2)$ & $90(66.2)$ \\
\hline Sarikaya et al. ${ }^{[58]}$ & Turkey & $57(4.0)$ & $429(49.3)$ & $24(52.0)$ \\
\hline Shahab et al. ${ }^{[60]}$ & Indonesia & $17(4.2)$ & $104(26.2)$ & $276(69.6)$ \\
\hline Kang et al. ${ }^{[74]}$ & Korea & $34(6.8)$ & $233(46.4)$ & $235(46.8)$ \\
\hline Total $(N=1975)$ & Asia & $124(6.3)$ & $976(49.4)$ & $875(44.3)$ \\
\hline
\end{tabular}

The table shows higher prevalence of high-risk PCa in West Africa than in Asia $(P<0.00 \mathrm{I})$ but lower prevalence of intermediate-risk and low-risk PCa in West Africa than in Asia $(P<0.001$ and $P=0.004$, respectively) 
the prevalence of high-risk PCa is higher in West Africa than in Asia. The difference between the two regions could be accrued to large-scale PSA screening, early detection germline mutation in high-risk groups, and management of identified cases in Asia. ${ }^{[77,78]}$ The high frequency of PCa in the age group of 50-59 years [Table 1] further compounds the issue of high MIR in West Africa. ${ }^{[79,80]}$ This calls for a review of the starting age for PSA testing. Although Carlsson et al. ${ }^{[19]}$ advocate that screening should start at $\geq$ 50 years, it will be more appropriate for screening to start at $\geq 40$ years in West Africa, as earlier proposed by Vickers et al. ${ }^{[81]}$ considering that $18.9 \%$ of PCa in the region occurs in the age range of $50-59$ years. Thus, starting the screening exercise at $\geq 40$ years may forestall the progression of the disease and reduce the mortality rate of $\mathrm{PCa}$ in the age range of 50-69 years.

\section{RACE AND ANCESTRAL MIGRATION INFLUENCES ON INCIDENCE AND MORTALITY}

Ancestral migration has been shown to increase the incidence of PCa among Asians and Africans. ${ }^{[16]}$ In England, the age-standardized incidence rate (ASR) of PCa per 100,000 for Black African and Black Caribbean is 99.2 and 110.1, respectively, whereas that of white and Asian is 44.9 and 21.3, respectively. ${ }^{[82]}$ Interestingly, country-of-origin based GLOBACON estimate shows that ASR incidence of PCa for Black African and Black Caribbean is 21.1 and 71.1, respectively, whereas that of Asians ranges from 1.9 to 5.1. ${ }^{[82]}$ Possibly, emigrational amplification of mutated genes may be occurring considering the fact that the incidence of PCa in men living in West Africa (61.3-127) is lower than the incidence in men with African ancestry who are living in the Caribbean (56.4-304), United State (258.3) and Europe (139.3-647.0). ${ }^{[83]}$ As at 2004, the incidence-mortality ratio of $\mathrm{PCa}$ in Chinese men and Chinese-Americans is approximately 1:50 and 1:9, respectively. ${ }^{[84]}$ This further supports the fact that race and ancestral migration favors higher incidence rates of PCa in offspring. According to literature review carried out by Chung et al. ${ }^{[11]}$ in Asia countries, age, family history, consumption of fat, eggs, red meat, fat, and dairy are risk factors for PCa.

Higher mortality rate has also been reported in Black NonHispanics PCa patients (47.2\%) than in white Hispanic PCa (19.9\%). ${ }^{[14]}$ According to Heyns's review, the mortality ratio between blacks and whites diagnosed of PCa is 2.4:1. ${ }^{[85]}$ The race related differences in mortality of patients with PCa could be linked to variation of mutation frequency. This is buttressed by the fact that the prevalence of BRCA1 and BRCA2 are higher in blacks than in whites $(14.3 \%$ vs. $5.0 \%$ and $3.6 \%$ vs. $3.5 \%$, respectively), whereas the prevalence of ATM is higher in white than in blacks $(0.7 \%$ vs. $0.0 \%) .^{[86]}$ A recently published study reveals that the standard mortality rate (SMR) of BRCA1 and BRCA2 were 1.8 and 3.9, respectively. ${ }^{[50]}$ These reports suggest that ancestral or family history and environmental factors determine the degree to which an individual is affected by germline mutations.

\section{RELATIONSHIP BETWEEN RACE, FAMILY HISTORY, AND AGGRESSIVE PROSTATE CANCER}

PCa is the most inherited cancer. ${ }^{[27]}$ According to Pritchard, ${ }^{[87]}$ the prevalence of pathogenic germline mutation is higher in PCa patients who have a first degree relative with breast, ovarian or colorectal cancer (71\%) than in those without an affected first degree relative (22\%). The effect of family history is commonly seen in blacks than in Whites. ${ }^{[88]}$ In the USA, the prevalence of pathogenic mutation in BRCA1/2 is higher in African American (1.4\%) than in Caucasians $(1.0 \%) .{ }^{[63]}$ The reason for the difference could be due to some inherited genes or family history. This is underscored by the reports of Chandrasekar et al. ${ }^{[86]}$ which shows that the prevalence of hereditary PCa (HPC) are higher in blacks than in white, with differences of $1.2 \%$. According to Lindström et al. ${ }^{[89]}$ family history is strongly associated with lethal/aggressive PCa. Their study revealed that a poor father survival implies a poor son survival with hazard ratio of 2.07. Approximately $12 \%$ of DNA repair genes occur in men with metastatic PCa than in the general population. ${ }^{[88]}$ Following genome-wide investigations, approximately 163 single-nucleotide polymorphisms (SNPs) have been linked to the development of PCa. These SNP accounts for 28\% of the family history associated with PCa. Individually, these SNPs exact minor effects but collectively they prove debilitating. Individuals with the SNPs are considered to have low and high genetic risk score (GRS) than the general population when their risk odd ratios are less than 1 and greater than 1 , respectively. ${ }^{[90]}$ In other to identify men who should be actively monitored for PCa, GRS appears to be a broad and reliable risk index for PCa than DNA repair genes (BRCA2 and ATM) or family history. ${ }^{[90]}$ However, BRCA1/2 mutations are early indicators of $\mathrm{PCa}$, whereas ATM mutation identifies individuals at risk of developing aggressive or metastatic PCa. ${ }^{[50,88]}$ Thus, testing for a combination of GRS, BRCA1/2 and ATM with active follow up of positive individuals may reduce PCa related mortality to a great extent.

\section{CONCLUSION}

The high prevalence of high-risk PCa in Asia and West Africa, when compared with the USA, the UK, and Germany, 
could be a reflection of the level of screening and treatment of identified cases in both regions. The lower prevalence of high-risk PCa in Asia when compared with West Africa could be due to race, differences in family history and inherited germline mutations. However, it is unclear whether the low interest in identifying germline mutations in West African patients is due to low incidence of the disease in the subcontinent or lack of funds. Screening individuals who are aged $>50$ and $\leq 69$ years and with a family history of prostate, breast, ovarian or pancreatic cancer, or Lynch syndrome may improve stratification and eliminate the need to test the entire patients, thereby lowering the cost of testing for germline mutations. Testing for BRCA2, BRCA1 and ATM in selected patients who have GS $\geq 7$ or GG $\geq 3$, high prostate density, low prostate volume and PSA levels of $>4.0 \mathrm{ng} / \mathrm{mL}$ may aid early identification of men at risk of developing lethal or aggressive PCa.

\section{Financial support and sponsorship}

Nil.

\section{Conflicts of interest}

There are no conflicts of interest.

\section{REFERENCES}

1. Lakhtakia R, Bharadwaj R, Kumar VK, Mandal P, Nema SK. Immunophenotypic characterization of benign and malignant prostatic lesions. Med J Armed Forces India 2007;63:243-8.

2. Garg M, Kaur G, Malhotra V, Garg R. Histopathological spectrum of 364 prostatic specimens including immunohistochemistry with special reference to grey zone lesions. Prostate Int 2013;1:146-51.

3. Farooq S, Bilai S, Khaliq BI, Sidieq F, Aslam H, Shah I. The spectrum of histopathological patterns observed in prostate specimens in a tertiary care hospital in Kashmir. Int J Contemp Med Res 2019;6:D1-3.

4. Fitzmaurice C, Akinyemiju TF, Al Lami FH, Alam T, Alizadeh-Navaei R, Allen C, et al. Global, regional, and national cancer incidence, mortality, years of life lost, years lived with disability, and disability-adjusted life-years for 29 cancer groups, 1990 to 2016: A systematic analysis for the global burden of disease study. JAMA Oncol 2018;4:1553-68.

5. Small E. Cecil Textbook of Medicine, Prostate Cancer. Philadelphia: WB Saunders; 2004.

6. Mohler JL, Armstrong AJ, Bahnson RR, Boston B, Busby JE, D’Amico AV, et al. Prostate cancer, version 3.2012: Featured updates to the NCCN guidelines. J Natl Compr Canc Netw 2012;10:1081-7.

7. Epstein JI, Allsbrook WC Jr, Amin MB, Egevad LL; ISUP Grading Committee. The 2005 international society of urological pathology (ISUP) consensus conference on Gleason grading of prostatic carcinoma. Am J Surg Pathol 2005;29:1228-42.

8. Torre LA, Bray F, Siegel RL, Ferlay J, Lortet-Tieulent J, Jemal A. Global cancer statistics, 2012. CA Cancer J Clin 2015;65:87-108.

9. Chen SL, Wang SC, Ho CJ, Kao YL, Hsieh TY, Chen WJ, et al. Prostate cancer mortality-to-incidence ratios are associated with cancer care disparities in 35 countries. Sci Rep 2017;7:40003.

10. Donnelly DW, Gavin A, Downing A, Hounsome L, Kearney T, McNair E, et al. Regional variations in quality of survival among men with prostate cancer across the United Kingdom. Eur Urol 2019;76:228-37.

11. Chung BH, Horie S, Chiong E. Clinical studies investigating the use of leuprorelin for prostate cancer in Asia. Prostate Int 2020;8:1-9.
12. Culp MB, Soerjomataram I, Efstathiou JA, Bray F, Jemal A. Recent global patterns in prostate cancer incidence and mortality rates. Eur Urol 2020;77:38-52.

13. Bray F, Ferlay J, Soerjomataram I, Siegel RL, Torre LA, Jemal A. Global cancer statistics 2018: GLOBOCAN estimates of incidence and mortality worldwide for 36 cancers in 185 countries. CA Cancer J Clin 2018;68:394-424.

14. Taitt HE. Global trends and prostate cancer: A review of incidence, detection, and mortality as influenced by race, ethnicity, and geographic location. Am J Mens Health 2018;12:1807-23.

15. Chen R, Ren S, Yiu MK, Fai NC, Cheng WS, Ian LH, et al.; Chinese Prostate Cancer Consortium. Prostate cancer in Asia: A collaborative report. Asian J Urol 2014;1:15-29.

16. Baade PD, Youlden DR, Cramb SM, Dunn J, Gardiner RA. Epidemiology of prostate cancer in the Asia-Pacific region. Prostate Int 2013;1:47-58.

17. Henderson RJ, Eastham JA, Culkin DJ, Kattan MW, Whatley T, Mata J, et al. Prostate-specific antigen (PSA) and PSA density: Racial differences in men without prostate cancer. J Natl Cancer Inst 1997;89:134-8.

18. Hugosson J, Carlsson S, Aus G, Bergdahl S, Khatami A, Lodding P, et al. Mortality results from the göteborg randomised population-based prostate-cancer screening trial. Lancet Oncol 2010;11:725-32.

19. Carlsson S, Assel M, Ulmert D, Gerdtsson A, Hugosson J, Vickers A, et al. Screening for prostate cancer starting at age $50-54$ years. A populationbased cohort study. Eur Urol 2017;71:46-52.

20. Pashayan N, Pharoah P, Neal DE, Hamdy F, Donovan J, Martin RM, et al. Stage shift in PSA-detected prostate cancers-effect modification by Gleason score. J Med Screen 2009;16:98-101.

21. Garg V, Gu NY, Borrego ME, Raisch DW. A literature review of cost-effectiveness analyses of prostate-specific antigen test in prostate cancer screening. Expert Rev Pharmacoecon Outcomes Res 2013;13:327-42.

22. Awodele O, Adeyomoye AA, Awodele DF, Fayankinnu VB, Dolapo DC. Cancer distribution pattern in south-western Nigeria. Tanzan J Health Res 2011;13:125-31.

23. Imasogie DE, Azeke AT. Prostatic adenocarcinoma and prostatic intraepithelial neoplasia: A tale of the autopsy model in a Nigerian tertiary hospital. Niger J Surg Sci 2017;27:41-6.

24. Erhabor O, Zama I, Mainasara AS, Shehu RA, Iwueke IP, Festus A, et al. Prostate Specific Antigen (PSA) screening among apparently healthy men of African descent in Sokoto, North Western, Nigeria. Int Blood Res Rev 2014;2:37-47.

25. Akinremi T, Adeniyi A, Olutunde A, Oduniyi A, Ogo C. Need for and relevance of prostate cancer screening in Nigeria. Ecancermedicalscience 2014;8:457.

26. Ukoli F, Osime U, Akereyeni F, Okunzuwa O, Kittles R, AdamsCampbell L. Prevalence of elevated serum prostate-specific antigen in rural Nigeria. Int J Urol 2003;10:315-22.

27. Ikuerowo SO, Ajala MO, Abolarinwa AA, Omisanjo OA. Age-specific serum prostate specific antigen ranges among apparently healthy Nigerian men without clinical evidence of prostate cancer. Niger J Surg 2016;22:5-8.

28. Anunobi CC, Akinde OR, Elesha SO, Daramola AO, Tijani KH, Ojewola RW. Prostate diseases in Lagos, Nigeria: A histologic study with TPSA correlation. Niger Postgrad Med J 2011;18:98-104.

29. Nwafor CC, Keshinro OS, Abudu EK. A histological study of prostate lesions in Lagos, Nigeria: A private practice experience. Nig Med J 2015;56:338-43.

30. Ugwumba FO, Ozoemena OF, Okoh AD, Echetabu KN, Mbadiwe OM. Transvesical prostatectomy in the management of benign prostatic hyperplasia in a developing country. Niger J Clin Pract 2014;17:797-801.

31. Forae G, Obaseki DE, Aligbe JU, Ekanem VJ. Morphological patterns of prostatic lesions in Benin city, Nigeria: A twenty year retrospective study. Ann Trop Pathol 2011;2:23-8.

32. Dawam D, Rafindadi AH, Kalayi GD. Benign prostatic hyperplasia and prostate carcinoma in native Africans. BJU Int 2000;85:1074-7. 
33. Emokpae MA, Das SC, Orok T, Mohammed AZ, Hassan SA. Early detection of prostate cancer: Evaluating the diagnostic performance of prostate specific antigen by comparing with histological technique among Africans. Indian J Clin Biochem 2004;19:62-6.

34. Obiorah CC, Ofuru V. A Population based study of prostate cancer in rivers state, Nigeria. Int J Biomed Sci 2019;15:57-62.

35. Isiwele EM, Bassey IAE, Ikpi EE, Enakirerhi GE, Otobo FO, Essiet A, et al. Histopathologic patterns of urological malignancies in Calabar, SouthSouthern Nigeria: A ten-year review. J Cancer Tumor Int 2018;8:1-10.

36. Bassey IA, Isiwele EM, Debua A. Prognostication studies of prostate cancer in black Africa: Findings from Calabar, South-South, Nigeria. Int J Cont Med Res 2018;5:E1-5.

37. Abubakar M, Shehu SM, Ahmed SA, Liman AA, Akpobi KC, Mohammed A, et al. Adenocarcinoma of the prostate: Correlation between serum prostate-specific-antigen and Gleason grade group. Ann Trop Pathol 2018;9:126-30.

38. Agalliu I, Adebiyi AO, Lounsbury DW, Popoola O, Jinadu K, Amodu O, et al. The feasibility of epidemiological research on prostate cancer in African men in Ibadan, Nigeria. BMC Public Health 2015;15:425.

39. Oluwole OP, Rafindadi AH, SHehu MS, Samaila MOA. A ten-year stud of prostate cancer specimens at Ahmadu Bello University Teaching Hospital (A.B.U.T.H.), Zaria, Nigeria. Afr J Urol 2015;21:15-8.

40. Ikuerowo SO, Omisanjo OA, Bioku MJ, Ajala MO, Mordi VP, Esho JO. Prevalence and characteristics of prostate cancer among participants of a community-based screening in Nigeria using serum prostate specific antigen and digital rectal examination. Pan Afr Med J 2013;15:129.

41. Sapira MK, Obiorah CC. Age and pathology of prostate cancer in southsouthern Nigeria; is there a pattern? Med J Malaysia 2012;67:417-9.

42. Ajape AA, Ibrahim KO, Fakeye JA, Abiola OO. An overview of cancer of the prostate diagnosis and management in Nigeria: The experience in a Nigerian tertiary hospital. Ann Afr Med 2010;9:113-7.

43. Mohmmed AZ, Nwana EJC, Anjorin AS. Histopathological pattern of prostatic diseases in Nigerians. Afr J Urol 2005;11:33-8.

44. Aghaji AE, Odoemene CA. Prostatic cancer after prostatectomy for benign prostatic hyperplasia in Nigeria. East Afr Med J 2000;77:635-9.

45. Herget KA, Patel DP, Hanson HA, Sweeney C, Lowrance WT. Recent decline in prostate cancer incidence in the United States, by age, stage, and Gleason score. Cancer Med 2016;5:136-41.

46. Buie J, De Riese W, Sharma P. Smaller prostate volume is associated with adverse pathological features and biochemical recurrence after radical prostatectomy. Urol Sci 2019;30:255-61.

47. Jedinak A, Curatolo A, Zurakowski D, Dillon S, Bhasin MK, Libermann TA, et al. Novel non-invasive biomarkers that distinguish between benign prostate hyperplasia and prostate cancer. BMC Cancer 2015;15:259.

48. Page EC, Bancroft EK, Brook MN, Assel M, Hassan Al Battat M, Thomas S, et al.; IMPACT Study Collaborators. Interim results from the IMPACT study: Evidence for prostate-specific antigen screening in BRCA2 mutation carriers. Eur Urol 2019;76:831-42.

49. Leongamornlert DA, Saunders EJ, Wakerell S, Whitmore I, Dadaev T, Cieza-Borrella C, et al. Germline DNA repair gene mutations in youngonset prostate cancer cases in the UK: Evidence for a more extensive genetic panel. Eur Urol 2019;76:329-37.

50. Nyberg T, Frost D, Barrowdale D, Evans DG, Bancroft E, Adlard J, et al. Prostate cancer risks for male BRCA1 and BRCA2 mutation carriers: A prospective cohort study. Eur Urol 2020;77:24-35.

51. Horn T, Krönke M, Rauscher I, Haller B, Robu S, Wester HJ, et al. Single lesion on prostate-specific membrane antigen-ligand positron emission tomography and low prostate-specific antigen are prognostic factors for a favorable biochemical response to prostate-specific membrane antigen-targeted radioguided surgery in recurrent prostate cancer. Eur Urol 2019;76:517-23.

52. Ugare UG, Bassey IE, Jibrin PG, Ekanem IA. Analysis of Gleason grade and scores in 90 Nigerian Africans with prostate cancer during the period 1994 to 2004. Afr Health Sci 2012;12:69-73.
53. Uemura H, Ye D, Kanesvaran R, Chiong E, Lojanapiwat B, Pu YS, et al. United in fight against prostate cancer (UFO) registry: First results from a large, multi-centre, prospective, longitudinal cohort study of advanced prostate cancer in Asia. BJU Int 2020;125:541-52.

54. Awang A, Md Isa N, Yunus R, Azhar Shah S, Md Pauzi SH. Gleason scores in prostate needle biopsy and prostatectomy specimens in prostatic adenocarcinoma: A correlation study. Malays J Pathol 2019;41:253-7.

55. Heo JE, Ahn HK, Kim J, Chung BH, Lee KS. Changes in clinical characteristics of patients with an initial diagnosis of prostate cancer in Korea: 10-year trends reported by a tertiary center. J Korean Med Sci 2018;33:e42.

56. Xu Y, Yang X, Si T, Yu H, Zhang W, Li Y, et al. Clinicopathological and prognostic factors in 106 prostate cancer patients aged $\leq 55$ years: A single-center study in china. Med Sci Monit 2016;22:3935-42.

57. Zhu Y, Han CT, Chen HT, Liu F, Zhang GM, Yang WY, et al. Influence of age on predictiveness of genetic risk score for prostate cancer in a Chinese hospital-based biopsy cohort. Oncotarget 2015;6:22978-84.

58. Sarıkaya S, Resorlu M, Oguz U, Yordam M, Bozkurt OF, Unsal A. Evaluation of the pathologic results of prostate biopsies in terms of age, Gleason score and PSA level: Our experience and review of the literature. Arch Ital Urol Androl 2014;86:288-90.

59. Osman E, Gomha MA, Harb A, Aldayel A, Aloraifi I, Almousa R, et al. An early-detection programme for prostate cancer in Saudi men: A call from a tertiary-care centre in the eastern province. Arab J Urol 2014;12:187-91.

60. Shahab AA, Soebadi DM, Djatisoesanto W, Hardjowijoto S, Soetojo S, Hakim L. Prostate-specific antigen and prostate-specific antigen density cutoff points among Indonesian population suspected for prostate cancer. Prostate Int 2013;1:23-30.

61. Tsang CF, Tsu JH, Lai TC, Wong KW, Ho BS, Ng AT, et al. Pathological outcome for Chinese patients with low-risk prostate cancer eligible for active surveillance and undergoing radical prostatectomy: Comparison of six different active surveillance protocols. Hong Kong Med J 2017;23:609-15.

62. Graham J, Baker M, Macbeth F, Titshall V; Guideline Development Group. Diagnosis and treatment of prostate cancer: Summary of NICE guidance. BMJ 2008;336:610-2.

63. Petrovics G, Price DK, Lou H, Chen Y, Garland L, Bass S, et al. Increased frequency of germline BRCA2 mutations associates with prostate cancer metastasis in a racially diverse patient population. Prostate Cancer Prostatic Dis 2019;22:406-10.

64. Faraj SF, Bezerra SM, Yousefi K, Fedor H, Glavaris S, Han M, et al. Clinical validation of the 2005 ISUP Gleason grading system in a cohort of intermediate and high risk men undergoing radical prostatectomy. PLOS ONE 2016;11:e0146189.

65. Pierorazio PM, Walsh PC, Partin AW, Epstein JI. Prognostic Gleason grade grouping: Data based on the modified Gleason scoring system. BJU Int 2013;111:753-60.

66. Emiogun FE, Williams OO, Obafunwa JO. Epidemiology of prostate cancer in Nigeria: Observations at Lagos State University Teaching Hospital. Cancer Health Disparities 2019. [Ahead of Print]

67. Taguchi S, Uemura Y, Fujimura T, Morikawa T, Naito A, Kawai T, et al. Quantification of the individual risk of each Gleason pattern, including tertiary Gleason pattern 5, after radical prostatectomy: Development of the modified Gleason grade grouping (mGGG) model. BMC Cancer 2020;20:371.

68. Wei Y, Wu J, Gu W, Qin X, Dai B, Lin G, et al. Germline DNA repair gene mutation landscape in Chinese prostate cancer patients. Eur Urol 2019;76:280-3.

69. Cho M, Yoo S, Park J, Jeong CW, Ku JH, Kwak C, et al. Value of the new 5 -tiered prostate cancer grade group system on predicting oncological outcomes for radical prostatectomy population in Korea. Korean J Urol Oncol 2018;16:75-81.

70. Yeong J, Sultana R, Teo J, Huang HH, Yuen J, Tan PH, et al. Gleason grade grouping of prostate cancer is of prognostic value in Asian men. J Clin Pathol 2017;70:745-53. 
71. Khan MA, Shah H, Gul M. Prognostic stratification of prostatic cancer according to modified Gleason grading system. J Rawalpindi Med College 2016;20:281-4.

72. Epstein JI, Zelefsky MJ, Sjoberg DD, Nelson JB, Egevad L, MagiGalluzzi C, et al. A contemporary prostate cancer grading system: A validated alternative to the Gleason score. Eur Urol 2016;69:428-35.

73. Marshall CH, Fu W, Wang H, Baras AS, Lotan TL, Antonarakis ES. Prevalence of DNA repair gene mutations in localized prostate cancer according to clinical and pathologic features: Association of Gleason score and tumor stage. Prostate Cancer Prostatic Dis 2019;22:59-65.

74. Kang DI, Chung JI, Ha HK, Min K, Yoon J, Kim W, et al. Korean prostate cancer patients have worse disease characteristics than their American counterparts. Asian Pac J Cancer Prev 2013;14:6913-7.

75. Wang FB, Chen R, Ren SC, Shi XL, Zhu YS, Zhang W, et al. Prostate cancer antigen 3 moderately improves diagnostic accuracy in Chinese patients undergoing first prostate biopsy. Asian J Androl 2017;19:238-43.

76. Huang J, Reilly KH, Zhang HZ, Wang HB. Clinical evaluation of prostate cancer gene 3 score in diagnosis among Chinese men with prostate cancer and benign prostatic hyperplasia. BMC Urol 2015;15:118.

77. Kitagawa Y, Namiki M. Prostate-specific antigen-based population screening for prostate cancer: Current status in Japan and future perspective in Asia. Asian J Androl 2015;17:475-80.

78. Lee HY, Park S, Doo SW, Yang WJ, Song YS, Kim JH. Trends in prostate cancer prevalence and radical prostatectomy rate according to age structural changes in South Korea between 2005 and 2015. Yonsei Med J 2019;60:257-66.

79. Ifere GO, Abebe F, Ananaba GA. Emergent trends in the reported incidence of prostate cancer in Nigeria. Clin Epidemiol 2012;4:19-32.

80. Hsing AW, Yeboah E, Biritwum R, Tettey Y, De Marzo AM, Adjei A, et al. High prevalence of screen detected prostate cancer in West Africans: Implications for racial disparity of prostate cancer. J Urol 2014;192:730-5.
81. Vickers AJ, Ulmert D, Sjoberg DD, Bennette CJ, Björk T, Gerdtsson A, et al. Strategy for detection of prostate cancer based on relation between prostate specific antigen at age 40-55 and long term risk of metastasis: Case-control study. BMJ 2013;346:f2023.

82. Maruthappu M, Barnes I, Sayeed S, Ali R. Incidence of prostate and urological cancers in England by ethnic group, 2001-2007: A descriptive study. BMC Cancer 2015;15:753.

83. Odedina FT, Akinremi TO, Chinegwundoh F, Roberts R, Yu D, Reams RR, et al. Prostate cancer disparities in Black men of African descent: A comparative literature review of prostate canacer burden among black men in the United States, Caribbean, United Kingdom, and West Africa. Infect Agents Cancer 2009;4:52.

84. Zhang L, Wu S, Guo LR, Zhao XJ. Diagnostic strategies and the incidence of prostate cancer: Reasons for the low reported incidence of prostate cancer in china. Asian J Androl 2009;11:9-13.

85. Heyns CF. Is prostate cancer more common and more aggressive in African men? Afr J Urol 2008;14:66-74.

86. Chandrasekar T, Gross L, Gomella LG, Hegarty SE, Leong JY, Giri VN. Prevalence of suspected hereditary cancer syndromes and germline mutations among a diverse cohort of probands reporting a family history of prostate cancer: Toward informing cascade testing for men. Eur Urol Oncol 2020;3:291-7.

87. Pritchard CC. Molecular insights into the germline for prostate cancer initiation, progression, and aggressiveness. Can J Urol 2019;26:24-6.

88. Pritchard CC, Mateo J, Walsh MF, De Sarkar N, Abida W, Beltran H, et al. Inherited DNA-repair gene mutations in men with metastatic prostate cancer. N Engl J Med 2016;375:443-53.

89. Lindström LS, Hall P, Hartman M, Wiklund F, Grönberg H, Czene K. Familial concordance in cancer survival: A Swedish population-based study. Lancet Oncol 2007;8:1001-6.

90. Isaacs $\mathrm{WB}, \mathrm{Xu} \mathrm{J}$. Current progress and questions in germline genetics of prostate cancer. Asian J Urol 2019;6:3-9. 